operation than a work of art. It is, moreover, an art most difficult to communicate. It is only to be acquired by some persons, and that after years of toilsome effort, and even the most experienced find it impossible to reduce their method to any fixed rules or formulæ.

\section{INDIAN CASTINGS AT THE INDIAN AND COLONIAL EXHIBITION}

$A^{\mathrm{T}}$ the last meeting of the Iron and Steel Institute $\mathrm{Mr}$. C. Purdon Clarke, C.I.E., Keeper of the Indian Section, South Kensington Museum, read a paper "On Certain Descriptions of Indian Castings " as follows :-

The importation of partly manufactured material is at present exercising considerable influence over many of the native arts of Oriental countries and India. The supply of machine-made thread has doubled the village hand-looms in some districts of Madras, and gold thread from Germany has enabled the brocade weavers to compete with the imitation brocades sent in from Europe.

In some handicrafts, however, the supply of European material has produced a contrary effect. Iron and steel, bar and rod, have displaced an ancient industry, and sheet copper and brass have robbed the founder of half his work. Formerly the only means of producing sheet-metal was by hammering cast plates, an expensive method, only resorted to when thin flat coverings were required for wooden or other objects. For very large vessels, where weight was required to be kept down and strength maintained, hammered sheet was used; but generally the founder was employed, to save as much as possible the labour of forming the furnished castings which required but little beating out, trimming, and brazing.

In the case of a bowl, or flat jar with a narrow mouth, the founder would prepare a cast not unlike in shape and thickness that of an ordinary flower-pot saucer, from which, by constant hammering, the bulbous sides would be formed, projecting beyond the rim, which would remain of its first diameter and thickness. When finished, such a vessel would be nearly double the size of the first cast, and a remarkable example of the native knowledge of the composition of bronzes and annealing processes.

It is worthy of noting that the chief means of detecting modern from old Persian and Saracenic metal vessels is by examining the brazen joints, which in ancient vessels are rare. When not found, a close examination will show the vessel to be a thin casting, the ornamentation being by inlay, or chasing and hammering, which, being done after the cast is made, gives the reverse side the appearance of chased sheet metal.

So far as he could ascertain, there were three methods of casting practised in India. The first, by moulds in sand; the second, moulds in clay not unlike plasterers' piece-moulds; the third, clay moulds formed on a wax model, the cire perdu of Europe.

The first of these was well known in Europe, but the second was, he believed, now described for the first time. In preparing the mould, impressi ins of the various parts of the pattern are taken in clay, and these pieces when nearly dry are, after trimming, stuck neatly together, and kept in place by several layers of mud, in which some fibre is mixed. The mould when ready has but one vent, which, placed on the most convenient side, is carried up into a sort of bottle-neck. If the object is small, several moulds are attached together, and the vents united by a single short neck of clay, to which a crucible, inclosed in an egg-shaped ball of clay, is attached. The size of this crucible depends upon the exact amount of metal required to fill the mould or moulds; and this quantity being known by experience, the founder places it inside before closing up. No provision is made for the escape of air from the mould when the metal is poured in. The mould and crucible (now in one piece) is allowed to dry; and after several coats of clay, tempered with fibre, have also been well baked on by the sun, the furnace is prepared. This is simply a circular chamber about 2 feet 6 inches in diameter, 2 feet in height, with a perforated hearth and no chimney. Half filled with charcoal, a good heat is obtained by the use of several sheepskin bellows from beneath. When ready, as many moulds as the furnace will hold are placed in it, the crucible end of each being embedded in the fire. A cover is placed over, and the fire kept up until, upon examination, the moulds are found to be red hot. They are then taken, one at a time, and replaced in a reverse position, the crucibles being now above. The metal flows down into a red-hot mould, and penetrates the finest portions of the surface without suffering from air or chilling. The fire is allowed to gradually cool, and when the objects are broken out of their clay covering, the metal is soft and malleable.

The third manner of casting (that by the use of a wax pattern which is destroyed in the moulding) was well known, but in one particular case the process had been carried further than would be at first believed, and of this he would now attempt a description.

The object produced is an anklet, a flexible ring about 4 inches in diameter, made from an endless curb chain. Such curb chain trinkets are common in India, and are generally made from thick silver wire rings interlinked and soldered one by one. In this example the anklet is of bronze, and consists of a complicated chain of forty-three detailed links, the whole being cast by a single operation. The first part of the process is the preparation of a pattern in wax, a delicate work, each link having to pass through four others, and to bear three small knobs or rosettes. These are in two instances but ornaments : the third, however, serves as a channel for the metal to enter each ring.

Then commences the most difficult part of the work, each ring having to be slightly separated, and this is effected by painting in a thin coat of fine clay until there is sufficient to form a partition. Other coats of clay are added until a thickness of about half an inch is attained, when a groove is cut round the upper side of the ring, and deepened until the row of knobs is bared. The wax is then melted out, and the mould attached to a crucible as before described. When cast, and the mould broken away, the chain comes out inflexible, being attached to a rod which runs round where the groove was cut. This is broken off, and the chain is complete.

Having been consulted respecting the trades to be represented in the Indian Courts of the Colonial and Indian Exhibition, he recommended amongst others a good brassfounder to be sent. Dr. Tyler, who was charged with the collection of these artisans, engaged one of the best he could find, but up to the present the foundry is not in working order.

One of these combined crucible moulds was submitted for inspection, with fragments of another, also a cast curb chain anklet; the author concluding by thanking the members for this opportunity of publishing an interesting process.

\section{A NEW SPECTROMETER}

I $\mathrm{N}$ equipping the Physical Laboratory of University College, Dundee, I felt considerable difficulty in deciding on a spectrometer for accurate work; it was easy to get a simple instrument for qualitative experiments and rough quantitative work, but it was only after consulting several friends and communicating with two or three firms that about two years ago I wrote to Mr. Hilger, in the hope that from him we might obtain an instrument capable of working to as high a degree of accuracy as would enable our best students in the laboratory to do advanced work. Considering that a second of arc is by no means an unusual limit of error in angular measurement, and that it is of the order $\mathbf{1}: 1,000,000$, the whole circle being unit, we thought that while further capability in reading power would be more than counterbalanced by various indeterminate errors, yet it should be possible to obtain this accuracy with a suitable instrument.

Prof. Liveing was kind enough to give us valuable information about one of his own instruments, of which the plans were sent to us by $\mathrm{Mr}$. Hilger for inspection; and $\mathrm{Mr}$. Capstick and I finally decided to ask Mr. Hilger whether he could not arrange two microscopes on the instrument in place of the one which Prof. Liveing's has.

As a consequence, Mr. Hilger presented suggestions for a spectrometer which is now in this college, and is capable of reading directly to one second of arc and yielding reliable results. Its construction is very simple. The collimator stands on a heavy pillar by itself ; and the circle, divided to five minutes of arc on a ring $\mathrm{I}_{5}$ inches in diameter, with six radial spokes, is carried on another pillar. The telescope, counterpoised, turns on the same axis, but does not touch the circle at any point; and the reading is managed as follows: from the telescope-bearing a double girder with a semicircular plan tied across its diameter by tubes of brass stretches horizontally above the semi-circumference of the divided circle; to this girder are fixed, at its ends, 
two long focus microscopes, whose axes produced intersect the divided circle at the extremities of a diameter. They are read by means of a pointer and spider-line micrometer, whose head is divided into 300 parts, each of which represent; one second of arc. The microscopes are carried at such a height that they easily pass the collimator, and they can be read in any position, and the light from the collimator passes clear under the girder.

J. E. A. StegGali

THE ABACUS IN EUROPE AND THE EAST

$\mathrm{A}^{\mathrm{T}}$ a late meeting of the Asiatic Society of Japan (reported in the Fapan Mail), Dr. Knott read a paper on "The Abacus, and its Scientific and Historic Import." A portion of the paper described the various arithmetical processes connected with the soroban, the form of the abacus employed in Japan. The writer pointed out that in all arithmetical operations up to the extraction of the cube root, the soroban really possessed distinct advantages over ordinary ciphering. This in itself explained why the instrument, which in Europe is suggestive of an infant school, has in the East survived till the present day. The rest of the paper was a discussion of the peculiar position which the abacus, used in its widest signification, holds in the history of the progress of arithmetic and mathematics, and of science and civilisation generally. The following is an abstract of the argument, the ultimate object of which was to explain why the abacus had died in Europe but lived in China, and why the cipher system of numerals had grown up in India but not in China.

The abacus, as used in China and Japan, bears, on the surface of it, evidence of a foreign origin. The numbers are set down on it with the larger denomination to the left-a method which could hardly be believed to have been invented by the Chinese, who tend to work from right to left, and who have always named their compound numbers beginning with the higher denominations. The Chinaman says "one hundred forty-five," as the Englishman does ; but the Englishman once said "one hundred five-and-forty," as the German still does; while in some of the Aryan languages of India, and in the Arabic of to-day, the number is named "five-and-forty and one hundred." The Arab writes from right to left, so that, had the abacus been invented by such a people who, so to speak, both wrote and spoke inversely, it would have indicated the number as it does. In fact, the abacus could only have arisen in its present form amongst a people who either wrote and spoke directly, or wrote and spoke inversely. As a matter of history, the geographical home of the abacus is India, but, unless there is conclusive evidence to the contrary, we cannot regard it as an invention of Aryan Indians, who, although they wrote directly, spoke inversely. They probably borrowed it from the Semitic merchants, and these, with their inverse speaking and inverse writing, may have invented it, or perhaps received it from a direct-speaking, direct-writing people, such as the highly-cultured Accadians seem to have been. The abacus was evolved, no doubt, from the human hand, which, with its ten fingers, was the only counting-board used by primitive man. Its course of development is quite distinct from that of the symbolic representation of numbers. These latter we can trace through four stages, which may be called the pictorial, the symbolic, the decimal, and the cipher. The pictorial we find in the Egyptian hieroglyphic and the Accadian cuneiform ; the symbolic in the hieratic, Phœnician, Hebrew, Greek, Roman, and the host of systems which grew up with the development and spread of alphabets and syllabaries, and the decimal in the simplification of these which live to-day in the Chinese and Tamilic systems. Once the decimal stage was reached, its general similarity to the abacus indications suggested bringing them into still closer correspondence. This took place amongst the Aryan Indians, who, along with their brethren of the West, very soon discarded the abacus for the, to them, more convenient cipher notation. With the Chinese and Tamils, however, no advance was made in this direction, a fact especially surprising in the case of the latter, who have lived in close contact with peoples that have long used the cipher system of numerals. One reason for the Chinese conservatism in so adhering to an unwieldy notation might be their vertical mode of writing, with which no very striking similarity between their symbolising of numbers and the abacus columns would appear. But this does not explain the conservatism of the Tamils, who write from left to right, nor yet the persistence of the abacus for centuries face to face with the Indian cipher system. The explanation is rather to be found in the system of nomenclature, which, being direct both among the Chinese and the Tamils, fitted perfectly with the abacus indications. For this reason the manipulation of the abacus in China and Japan is more rapid and certain than ciphering, and hence, there being no advantage for simple arithmetical operations in tne latter, the cipher system did not develop in these countries, and even when introduced from the West in all its vigour could not displace "the rod and the beads." An Aryan Indian, with his inverse-speaking, could never work the abacus with the same facility as the Japanese unless he worked from right to left, a mode of procedure quite foreign to his nature. It is not so foreign to the Chinese and Japanese, however, to work from left to right, as shown in the formation of each individual ideograph employed in writing. Hence the abacus suited the Chinese language better than it did any of the Aryan languages in their original mode of numbernaming. The influence of the notation which was developed from Semitic sources under the influence of the abacus, has in later times compelled many of the Aryan languages to assimilate as far as possible to the direct mode of numeration; but in the English fifteen, the German fünfzehn, and the French quinze, we still have the relics of the original inverse mode of naming, alike peculiar to Aryan and Semitic peoples.

In the course of the discussion which followed, it was mentioned that Chinese mathematics were first studied in Japan about 900 A.D., and that the Japanese ascend by powers of Io, 000 in their treatment of larger numbers.

\section{THE GAZETTEER OF RUSSIA}

$W^{E}$ have received the concluding fascicule of the "Geographical and Statistical Dictionary of the Russian Empire," published by the Russian Geographical Society, and edited by M. P. Semenoff. This monumental work, which was begun more than twenty years ago, has been now concluded in five large octavo volumes, and will remain for many years the most trustworthy and c smplete source of information for the geography of the empire, exclusive of Poland, but inclusive of the former Russian dominions in America. It may be regretted that the editor of the "Dictionary" has been diverted by so great a variety of gengraphical, statistical, and administrative work from this undertaking, and that therefore the last fascicule appearing twenty-three years after the first, the statistical information contained in the first fascicules and volumes has become out of date. But notwithstanding that, the "Dictionary" has not become old. Its value is not in the statistical data it contains; it is much more in the excellent geographical descriptions of the localities treated-that is, of each separate government of Russia, Siberia, Turkestan, and Caucasus-of the seas that border Russia, and their islands. Several articles are excellent and most complete monographs, and we need only mention those on the Amur, Caucasus, Sakhalin, the Northern Ocean, or Turkestan to remind geographers of these excellent descriptions of whole regions. The geology, the flora and fauna of each region have received much attention. These descriptions will not soon be old--they can be only conipleted.

At the end of each article there is, moreover, a most complete bibliography of the larger geographical works in which the place described in the article has been mentioned, as also of monographs dealing with it, and of newspaper articles. This bibliography is invaluable for the geographer. On the whole, the equally high standard of all geographical descriptions and the unity of conception in all of them-the whole being the work of the editor himself, assisted only by M. Zverinsky and very few occasional contributors--make this "Dictionary" occupy one of the first ranks among like publications. An appendix is promised, which will contain descriptions of such regions as the Thian-Shan, Ferganah, and Transbaikalia, which were much explored during the publication of the "Dictionary." They will embody all recent information.

\section{UNIVERSITY AND EDUCATIONAL INTELLIGENCE}

Con vocation of the University of London met on Tuesday evening to consider the report of a Special Committee which proposed several important changes in the constitution of the

I “Geographitchesko-Statistitcheskiy Slovar Rossiyskoy Imperii,' P. P. Semenova. 